\title{
A Relationship in Limbo: Challenges, Dynamics and Perspectives of Kosovo's Integration into NATO
}

Besfort T. Rrecaj

\section{Abstract}

Since its declaration of independence Kosovo has clearly postured itself towards Euro-Atlantic integration with NATO, keeping its door open towards Western Balkan states. This integration process faces major challenges stemming from different dimensions: NATO's internal unity and its stance towards Kosovo's political status having direct impact in consensual decision making processes; current geopolitical tensions from a global perspective, particularly between the West and Russia; and Kosovo's ability to fulfil NATO's standards and criteria. These challenges might prove very difficult to overcome at least in the current global political and security environment. The objective of this paper is to discuss from legal and geopolitical perspectives the relations between Kosovo and NATO and the challenges, dynamics and perspective of NATO opening a formal integration process for Kosovo.

\section{KEY WORDS:}

NATO and UN, NATO and KFOR, Kosovo Armed Forces, Kosovo and NATO non-recognizers, security generator. 
NATO's official integration policy for the Western Balkan countries remains open, leaving a glimpse of hope for countries like Kosovo to join the alliance in the future. Kosovo declared its independence on 17 February 2008 and has since clearly postured itself towards Euro-Atlantic integration. However, with four member states' still refusing to recognize Kosovo as a sovereign and independent state, NATO is a divided organization where decisions are taken on a consensual basis. Aside from internal issues, another obstacle for Kosovo may lie in the fact that the United Nations Security Council (UNSC) Resolution 1244 is still in force, with Russia's stance to veto any decision to abrogate it. This may have a crucial impact on the ability of NATO to take a decision, even in the absence of internal divisions. This becomes evident due to the primary role of, and enhanced relations between, the UNSC and NATO regarding global peace and security. Any negligence towards the UNSC may trigger negative reactions by Russia which in turn might jeopardize NATO's relations with the UN and thus its position in the world, especially outside of NATO's area. To make matters more complex, current deteriorating relations between Russia and the West over several issues, perhaps the most important of which is Ukraine and Crimea, will make the UNSC even more incapable of taking any decision to replace or modify UNSC Resolution 1244, which in turn reflects negatively on Kosovo. Ultimately, the integration process will depend on the ability of Kosovo to prove itself to be a genuine democratic state, upholding the basic fundamental principles of rule of law, respect for human rights and development of a free market economy. Good neighborly relations and internal stability would place Kosovo in the list of security generators, a key category for a country wishing to join NATO. In this regard, normalization of relations between Serbia and Kosovo is seen as an important step in improving regional peace and security. Inherent in this analysis is the future of the Kosovo Army, which is supported by Kosovo's main allies, while being fiercely opposed by Serbia and Russia. 


\section{NATO's mission, enlargement policy and partnerships}

NATO is a state based organization founded around the idea of collective defence ${ }^{2}$ (Kenan 1947; Dudziak 2012). Its international legitimacy derives from article 51 of the UN Charter, allowing for individual or collective selfdefence of states in a world of no supranational state like institution that can subsume the will of individual states (UN Charter 1945, Art 2(4)). The primary objective of NATO still remains the preservation of security and peace of all its members using necessary and available diplomatic and non-diplomatic means. According to the preamble of the treaty:

"They [state parties] are determined to safeguard the freedom, common heritage and civilization of their peoples, founded on the principles of democracy, individual liberty and the rule of law"... and ... "to unite their efforts for collective defence and for the preservation of peace and security" (North Atlantic Treaty 1949, Preamble).

The cornerstone of the North Atlantic Treaty is Article 5 stating the principle of collective defence:

"... an armed attack against one or more of them in Europe and North America shall be considered and attack against them all and consequently they..., will assist the Party or Parties so attacked by taking forthwith, individually and in concert ..., such actions as it deems necessary, including the use of armed force, to restore and maintain the security ...." (North Atlantic Treaty, Art. 5).

In more than 60 years of existence, NATO has invoked Article 5 only once,

2 The NATO founding document was signed on 4 April 1949 in Washington D.C. by 12 states from Western Europe and North America and is referred to as the Washington Treaty or the North Atlantic Treaty (Treaty). It required US reassurance in the region at times of wider global challenges. A crucial factor in designing this new American foreign policy was played by the US Ambassador to Moscow, George Kennan, who, after seeing the USSR's tendencies and actions in Europe, insisted on a more proactive policy by the US if it wants to save Europe from Stalin. Kennan appealed to the President of the US to use all necessary economic and military force to save the Western World from Stalin. Kennan's appeal prompted the development of the so called Truman Doctrine, resting on two pillars: support for free peoples resisting attempted subjugation by armed minorities or outside pressure; and to preserve the political integrity of democratic nations.

3 For more on Article 5 in a contemporary perspective see Botticelli (2002). 
a powerful indicator showing that NATO managed to deter any possible attack by its mere existence, its real capabilities and its determination. In fact, it was the terrorist attack by $A /$ Qaeda of 9/11 which prompted NATO to trigger Article 5 by calling all NATO member states to help the US in repelling any attack, in defence of NATO territory (NATO 2015a). In another case, after the Paris attacks in 2015, the French President fell short of triggering Article 5, even though France acknowledged the terrorist attack as an act of war, leading to a state of war between France and ISIL (Stavridis 2016). Today, Article 5 is interpreted much wider, in response to contemporary challenges such as cyber-attacks as the fifth domain of warfare (NATO 2016; Todd 2009; Augustine 2014).

From its inception in 1949, NATO has grown to become an organization of 29 fully-fledged member states. ${ }^{4}$ Article 10 is the core Article of the Treaty, guiding NATO's enlargement, and keeping the door open to any:

"European State in a position to further the principles of this Treaty and to contribute to the security of the North Atlantic area" (NATO 2016, Art.10).

On a more technical note, the 1995 Study on Enlargement remains a key document laying down basic principles for future enlargement. These principles require prospective member states to adhere to basic UN Charter principles, uphold NATO values, internal stability, strengthen trans-Atlantic partnership, show an ability and willingness to commit military and political support to NATO's future operations, and the ability to become a security generator (NATO 2008). To facilitate this process for prospective members, NATO designed the Membership Action Plan (MAP) to assist aspirant partner countries in their preparations by providing advice, assistance and practical support. It enables states to be able to provide for security within the alliance and outside of it ${ }^{5}$ (NATO 2015b; NATO Handbook 2006).

4 Today NATO counts 29 member states: Albania, Belgium, Bulgaria, Canada, Croatia, the Czech Republic, Denmark, Estonia, France, Germany, Greece, Hungary, Iceland, Italy, Latvia, Lithuania, Luxembourg, Montenegro, the Netherlands, Norway, Poland, Portugal, Romania, Slovakia, Slovenia, Spain, Turkey, the United Kingdom and the United States.

5 Facilitated by the MAP, Bulgaria, Estonia, Latvia, Lithuania, Romania, Slovakia and Slovenia became fully fledged NATO members in 2004. Albania, Croatia (2009) and Montenegro (2017) also went through the same process. A special Individual Membership Action Plan was designed for Serbia. The MAP still remains out of reach for Kosovo. 
Furthermore, the current Strategic Concept guides NATO to keep its door open for future prospective members:

"The door to NATO membership remains fully open to all European democracies which share the values of our Alliance, which are willing and able to assume the responsibilities and obligations of membership, and whose inclusion can contribute to common security and stability." (NATO 2016)

Enlargement is backed by a consensual decision making process, requiring that no state opposes the inclusion of a new NATO member. On the positive side this decision making process has a crucial impact on the ability to implement any decisions taken and also preserves NATO's cohesion. However, on the negative side, a decision making process based on consensus might prove difficult to achieve, especially as membership enlarges. This may harm the unity, ability and reputation of NATO to react in complex political situations (NATO 2015c).

NATO's membership was expanded in seven main rounds during the Cold War and after. Greece, Turkey, West Germany and Spain became NATO members during the Cold War, in 1952, 1955 and 1982 respectively. Other states from the East of Europe became members in the last four rounds in 1999, 2004, 2009 and 2016. As the Cold War ended, states belonging to the Warsaw Pact, faced with political, economic and military difficulties, became eager to join NATO in order to preserve their freedom; thus, these states came knocking on the doors of NATO for membership. The reunification of West and East Germany marked a particular feature which saw a former state of the Warsaw Pact becoming part of NATO (Walker 2015). Montenegro was asked to join the alliance in the Warsaw Summit of 2016 and became full-fledged member in 2017 (NATO 2017), placing the whole of the Adriatic's shores under NATO's control and finally encircling the remaining Western Balkan states within NATO's area. ${ }^{6}$

From a broader perspective, in 1997 NATO established the Euro-Atlantic Partnership Council (EAPC), representing today a partnership of 50 states including 29 current members and 21 partner states. The EAPC's aim is to facilitate enhanced political and security communication between

6 NATO member states Croatia, Romania, Bulgaria, Greece, Albania and Montenegro encircle the Western Balkans states Kosovo, Serbia, Macedonia and Bosnia and Herzegovina. 
NATO and its partners. The partnership focuses on different important issues such as management of crisis situations, armament control, safety of nuclear facilities, the fight against terrorism, proliferation of weapons of mass destruction (WMD) etc. The Partnership for Peace (PfP) does not entail any guarantees for future membership; however, it is based on core NATO values (NATO 2014a). In 2011, NATO approved a new partnership policy in line with the new Strategic Concept which conceptualizes key areas of cooperation to enhance political consultation and cooperation in NATO missions, reform of the defence sector, the fight against terrorism, and countering WMD and related issues (NATO 2014a).

In line with the open door policy and NATO's willingness to enlarge its partnerships, in early 2016 Kosovo's Prime Minister sent an official letter to the NATO Secretary General, asking for enhancement of relations and possibly including Kosovo in a PfP program. In his rather vague response letter, Mr. Secretary Stoltenberg stated that NATO's mission in Kosovo will remain under its current mandate (meaning under UNSC Resolution 1244), but they will seek new opportunities to cooperate with the Kosovo Security Forces (KSF). These opportunities include more exchange visits from Brussels to Prishtina and vice versa, boosting dialogue and practical cooperation, building the integrity of relevant institutions, and partial participation in the "Science for Peace and Security" programme (Office of the Prime Minister of Kosovo 2017). As good as it may sound, this letter avoids mentioning any fundamental and formal enhancement of relations and as such it does not give a clear perspective regarding any NATO-KOsOvo partnership. Also, the letter fails to address any transformation of the KSF into a new, formal military structure.

\section{Challenges, opportunities and perspectives for Kosovo to join NATO in the current geopolitical context}

From the formal legal point of view, The Republic of Kosovo has aligned itself clearly towards Euro-Atlantic integration. This stance is cemented in 
the Declaration of Independence and the Constitution of Kosovo. The Declaration of Independence in its preamble states Kosovo's reaffirmation and wish to

"become fully integrated into the Euro-Atlantic family of democracies." (Kosovo Declaration of Independence 2008)

It commits Kosovo to embrace values which are intrinsic to NATO. In this perspective, paragraph 2 of this declaration states that:

"We [the people of Kosovo] declare Kosovo to be a democratic, secular and multiethnic republic, guided by the principles of non-discrimination and equal protection under the law." Kosovo Declaration of Independence 2008)

Further it commits Kosovo to:

"abide by the principles of the United Nations Charter, the Helsinki Final Act, other acts of the Organization on Security and Cooperation in Europe and the international legal obligations and principles of international comity" (Kosovo Declaration of Independence 2008).

The principles stated in the Declaration of Independence are further elaborated in the Constitution of Kosovo. In its preamble the Constitution states the intention of:

"having the state of Kosovo fully participating in the processes of Euro-Atlantic integration." (Constitution of Kosovo, Preamble 2008)

The constitution declares Kosovo a free, democratic and peace-loving country, promising to be a state of free citizens, guaranteeing basic rights and equality of all citizens before the law. Article 7 of the Constitution stipulates:

"1. The constitutional order of the Republic of Kosovo is based on the principles of freedom, peace, democracy, equality, respect for human rights and freedoms and the rule of law, non- 
discrimination, the right to property, the protection of environment, social justice, pluralism, separation of state powers, and a market economy." (Constitution of Kosovo, Art. 7)

Furthermore, Article 10 establishes Kosovo's economic system:

"A market economy with free competition is the basis of the economic order of the Republic of Kosovo." (Constitution of Kosovo, Art. 10)

Article 17 of the Constitution opens the way for Kosovo to enter into international agreements that include agreements for the purpose of protection of peace security and human rights.

1. "The Republic of Kosovo concludes international agreements and becomes a member of international organizations.

2. The Republic of Kosovo participates in international cooperation for promotion and protection of peace, security and human rights." (Constitution of Kosovo 2008, Art 17)

Article 125.4 of the Constitution guarantees:

"Civilian and democratic control over security institution..." (Constitution of Kosovo 2008, Art 125.4)

Kosovo embraces liberal-democratic values and has taken maximum guarantees for the protection of human rights, minority rights and a functioning market economy. These values have to be enforced in reality; however, formal posture is the first step in the process. Kosovo has a peculiar relation with NATO, particularly due to NATO's intervention in 1999 (NATO 1999). Since then, NATO has been involved in Kosovo as a peacekeeper, however, as a state Kosovo does not yet have any formal relations with NATO (NATO n.d.a). Nevertheless, Kosovo has developed itself in many areas which might help it fulfil the standards stipulated by NATO. This is partially due to KFOR's presence in Kosovo and its role in the development of the Kosovo Security Forces (KSF), and also due to its relations with the European Union (EU) (NATO n.d.b). Kosovo is monitored on a regular basis by the European Commission (EC), through its yearly published Progress Report which analyses the progress made by Kosovo 
on three main criteria: political, economic and European standards deriving from the EU Copenhagen Summit (European Commission n.d.a). The Kosovo-EU relationship culminated with the signing of the Stabilization and Association Agreement (European Commission n.d.b). Therefore the EU, while monitoring fulfilment of standards for its own agenda, indirectly impacts the improvement of values falling within the scope of NATO integration and which will be very useful in the future when the formal integration process begins.

From the point of view of security, NATO's KFOR mission has been a key player in Kosovo, managing the security situation after the end of the war in Kosovo in 1999. NATO's peacekeeping operation in Kosovo followed the 78-day air campaign against military targets of the Federal Republic of Yugoslavia, mainly throughout Serbia and Kosovo, in order to stop ethnic cleansing and other human rights atrocities against Kosovan Albanians $^{7}$ (NATO Handbook 2006: 149-152). On 9 June 1999 diplomatic efforts managed to broker a Military Technical Agreement signed by NATO and the Federal Republic of Yugoslavia. Following this, UNSC Resolution 1244, promulgated on 10 June 1999, under chapter VII, established UN Administration in Kosovo pending final status settlement. The Military Technical Agreement was annexed to Resolution 1244 and KFOR started operating under a UN mandate (UNMIK 2017). The main tasks of KFOR in Kosovo have not changed a lot since then, and include the following:

- "Contribute to a safe and secure environment;

- Support and coordinate the international humanitarian effort and civil presence;

- Support the development of a stable, democratic, multi-ethnic and peaceful Kosovo;

- Support the development of Kosovo Security Force." (NATO 2017)

Today, KFOR's mission in Kosovo involves approximately 5,000 troops, down from more than 50,000 troops in 1999, still operating under UNSC Resolution 1244. These troops assist the UN, the EU and national authorities in developing a stable, democratic, multi-ethnic and peaceful Kosovo

7 The conflict in Kosovo resulted with close to 1 million refugees who found refuge mainly in Albania, Macedonia, Montenegro and Bosnia and Herzegovina. In Kosovo it was estimated that around 580,000 people were left homeless. 
(NATO 2017). A key task for KFOR was to assist in the transformation of the Kosovo Liberation Army (KLA). KFOR was the main actor in overseeing this process, with the help of national authorities in Kosovo. In 1999, the KLA was transformed into the Kosovo Protection Corps (KPC) taking on civilian duties. Later, in June 2008, NATO agreed to transform the KPC into the lightly armed KSF again, with civilian duties such as response to crisis situations, assisting responsible authorities to manage natural and other emergencies, civil protection and explosive ordinance disposal (Wiseman 2001; Clewlow 2010). The KSF works under civilian control by the Ministry for Kosovo Security forces, which is also vested with the powers of management and administration of the KSF. The KSF is accountable to the Assembly of Kosovo and reports through the Prime Minister. The Commander in Chief of the KSF is the President of Kosovo (Constitution of Kosovo 2008, Art. 84 (12)). A marked feature in the development of its operational capabilities was a declaration by NATO on 9 July 2013, which determined that "the KSF is now capable of performing the missions and tasks assigned to it" (NATO 2013). This may be a crucial moment for the next decision to start the final transition, which is the decision to establish a Kosovan Army with military responsibilities.

However, Kosovo's integration into NATO seems to be a very complex process with no clear signs of beginning and certainly not ending. This is due to many factors but the factors below might play a crucial role:

1. NATO internal division regarding the political status of Kosovo;

2. NATO relations with the UN and the UNSC; and

3. Kosovo's ability to rise to NATO standards and generate security.

With regards to the first factor, NATO is facing internal division regarding the international political status of Kosovo, as 4 out of 28 members do not recognize Kosovo as a sovereign and independent state. These states are Spain, Romania, Slovakia and Greece. Any of the four non-recognizers may block any decision to start a formal integration process. The NATO integration process is first and foremost a political process and political disagreements over the international political status of Kosovo have direct impact on decisions taken by NATO. The case of Macedonia shows how one NATO member state, in this case Greece, may block membership 
of one country due to political disagreements, which in this case was the dispute over the official name of Macedonia ${ }^{8}$ (The Former Yugoslav Republic of Macedonia v. Greece (2011) ICJ General List no. 142).

Nevertheless, a positive comparison case may be drawn in Kosovo's relations with the EU. The EU managed to overcome similar issues with its 5 non-recognizing states (all of the four NATO non-recognizers above, plus Cyprus), after an agreement between Kosovo and Serbia for regional representation of Kosovo was achieved (Office of the Prime Minister of Kosovo 2012). This agreement and the whole process of normalization of relations between Kosovo and Serbia, facilitated by the EU, had a profound effect for this organization to proceed with the signing of the Stabilization and Association Agreement (European Council 2011) with Kosovo, the first contractual relationship between Kosovo and the EU (Office of the Prime Minister of Kosovo n.d.). The question may naturally arise as to the use of the same precedent by NATO to enhance and possibly formalize the integration process for Kosovo. However, the glitch here is that the agreement between Kosovo and Serbia is limited to regional representation for Kosovo. The EU is a regional European organization, while NATO is not a typical regional organization because it is composed of members from both sides of the Atlantic. This broader geographical scope lessens the importance of regional agreements, and may give an opportunity for NATO non-recognizers to stay their course towards Kosovo.

The second challenge arises from the very nature of NATO as a security organization and its relations with the UN and one of its main organs in particular, the UNSC. NATO, in a broader sense, operates within the framework of the UN Charter. The UN Charter identifies the UNSC as the principal organ with primary responsibility over peace and security in the world (UN Charter 1945, Art. 24).

To the same effect, Article 7 of the North Atlantic Treaty stipulates that NATO member states have undertaken to not affect:

8 Macedonia's official and formal reference by its constitution is The Republic of Macedonia while Greece recognizes it with the name Former Yugoslav Republic of Macedonia which is part of the interim accord signed by the parties on 13 September 1995. Macedonia sued Greece at the International Court of Justice which came to the conclusion that Greece did not have the right to block Macedonia's bid for NATO membership on the basis of the name dispute. 
"In any way the rights and obligations under the Charter of the Parties which are members of the United Nations, or the primary responsibility of the Security Council for the maintenance of international peace and security." (North Atlantic Treaty, Art. 7)

The relationship between the UNSC and NATO is multifold. NATO operates under the UNSC's mandate in many countries, such as Bosnia and Herzegovina, Afghanistan, Libya and Iraq. NATO is also involved in supporting UN operations in different parts of Africa, Pakistan and Somalia. In 2008, NATO and the UN moved to sign a declaration of cooperation in what may be seen as the first step in the formalization of this relationship (NATO 2014b).

In this regards, NATO is involved in Kosovo under the umbrella of UNSC Resolution 1244, which still remains in force. This resolution sees Kosovo as a territory under UN administration, leaving the issue of final status open for future discussion (UNSC Resolution 1244 1999). After Kosovo's Declaration of Independence' (ICJ 2008), the UNSC did not move to abrogate Resolution 1244, due to its internal divisions and Russia's threat to veto such a move. In these circumstances, NATO reaffirmed its stance that its KFOR mission shall remain in Kosovo based on UNSC Resolution 1244 until the approving organ of the resolution decides otherwise (NATO n.d.c). Hence, should NATO decide to enter into any formal relationship with Kosovo it might raise tensions with particular members of the UNSC, such as Russia and possibly China, which in turn may jeopardize relations between NATO and the UN in general. The situation becomes more complicated in cases when relations between the UNSC permanent members deteriorate. Such deterioration might exist today between the West and Russia over the crisis in Ukraine and Syria, i.e. from this perspective, Kosovo might become collateral damage in a clash of titans over global issues. As the current global standing persists, it seems that, in the near future, the UNSC will find it very difficult to change its stance and reflect on the reality of independent Kosovo having direct impact on NATO's stance on Kosovo, and possibly prolong the current format.

The third important challenge relates to rising to NATO standards and Kosovo's ability to generate security. These are two crucial factors to be

9 Kosovo declared its independence on 17 February 2008, and the ICJ confirmed that this declaration does not violate any provision of international written or customary law, nor UNSC Resolution 1244. 

on NATO Enlargement stipulate the concept of stability and security and how they see a member state at the time they join; new member states must commit themselves to democratic development, good neighbourly relations, contribute to international security etc. ${ }^{10}$ (NATO 1995 Study on Enlargement 2008, Para. 3 and 5).

Kosovo still has the KFOR presence as peacekeepers to guarantee the peace between Serbia and Kosovo, and also Kosovo's internal security. The Kosovo-Serbia agreements on normalization of relations have improved the security situation. Among other things, these agreements have particular provisions related to the integration of Kosovan Serbs within Kosovo (Office of the Prime Minister of Kosovo n.d.). The end of this process is supposed to bring a situation to the point when relations between Kosovo and Serbia would be conducted at the level of a normal bilateral relationship with full integration of Kosovan Serbs in Kosovan institutions and in daily public life. In turn, this would create a situation where the presence of KFOR in Kosovo is no longer necessary. This might be Kosovo's first step towards pulling off its veil of 'security consumer' and start to make its first steps towards generating security. This would involve being ready to participate actively in the region and elsewhere when needed, and being capable in this regard.

10 Paragraph 3 of the 1995 Study states:

"Therefore, enlargement will contribute to enhanced stability and security for all countries in the Euro-Atlantic area by:

- Encouraging and supporting democratic reforms, including civilian and democratic control over the military;

- Fostering in new members of the Alliance the patterns and habits of cooperation, consultation and consensus building which characterize relations among current Allies;

- Promoting good-neighbourly relations, which would benefit all countries in the Euro-Atlantic area, both members and non-members of NATO;

- Emphasizing common defence and extending its benefits and increasing transparency in defence planning and military budgets, thereby reducing the likelihood of instability that might be engendered by an exclusively national approach to defence policies;

- Reinforcing the tendency toward integration and cooperation in Europe based on shared democratic values and thereby curbing the countervailing tendency towards disintegration along ethnic and territorial lines;

- Strengthening the Alliance's ability to contribute to European and international security, including through peacekeeping activities under the responsibility of the OSCE and peacekeeping operations under the authority of the UN Security Council as well as other new missions;

- Strengthening and broadening the Trans-Atlantic partnership."

- Paragraph 5 of the 1995 Study:

- "New members, at the time that they join, must commit themselves, as all current Allies do on the basis of the Washington Treaty, to:

- Unite their efforts for collective defence and for the preservation of peace and security; settle any international disputes in which they may be involved by peaceful means in such a manner that international peace and security and justice are not endangered, and refrain in their international relations from the threat or use of force in any manner inconsistent with the purposes of the United Nations;

- Contribute to the development of peaceful and friendly international relations by strengthening their free institutions, by bringing about a better understanding of the principles upon which these institutions are founded, and by promoting conditions of stability and well-being;

Maintain the effectiveness of the Alliance by sharing roles, risks, responsibilities, costs and benefits of assuring common security goals and objectives." 
Another issue which may come to our attention has to do with the status of the Kosovo Security Forces and its transformation into a Kosovan Army. This transformation process, considered to be one of the most important steps in consolidating Kosovo's independence, has gathered steam recently with Kosovo's government pushing for the necessary legal changes for this process. Constitutional changes, preferred by Kosovo's allies and NATO, require so called 'double majority voting', which means that the constitutional amendment will only be considered as approved if 2/3 of all 120 deputies vote in favour, including $2 / 3$ of all deputies holding non-Albanian guaranteed seats (Constitution of Kosovo, Art. 144). Non-Albanian communities hold 20 seats out of which 10 belong to the Serbian community. This basically gives the Serbian community the right to veto any such process (Hopkins 2017). From a broader perspective, Serbia and Russia remain heavily opposed to this idea, considering it as a threat to regional security and cooperation (Sputnik 2013). On the other hand, Kosovo's main ally, the US, and NATO, oppose any move without exhausting proper constitutional amendment procedures, therefore halting the whole idea until the Serbian community agrees (Bytyci 2017). Therefore, the creation of Kosovo's Armed Forces remains at a halt until a common solution is found within constitutional requirements.

Within these circumstances a question arises as to whether a state needs to have a standing army in order to become a NATO member. Article 10 of the NATO Treaty does not require per se a prospective member country to have a standing army. Article 10 reads as follows:

"The Parties may, by unanimous agreement, invite any other European State in a position to further the principles of this Treaty and to contribute to the security of the North Atlantic area to accede to this Treaty..." (North Atlantic Treaty 1949, Art. 10)

In this regard, an explanatory example may be drawn from the case of Iceland, which does not have a standing army but is a fully fledged NATO member (Ministry of Foreign Affairs of Iceland n.d.). Along the same lines, the 1995 Study does not require any future member to have a standing army while reaffirming the conditions stipulated in Article 10. Paragraph 43 of this study states that new member states "may" be asked to contribute appropriately to the "Alliance's military force and command and structure and infrastructure" (NATO 1995 Study on Enlargement 2008, Para 
43). As to the concept of giving appropriate contributions to the Alliance, this may also include logistical support and other supporting activities to the Alliance's military forces, without the need to have a standing army. Nevertheless, establishing a standing army from the foundations of the KSF, based on NATO standards, would consolidate the state of Kosovo and give it an additional ability to generate security within the NATO area and elsewhere in its missions.

In the midst of these challenges Kosovo would benefit a lot if given the chance to participate in the PfP programme. This would help Kosovo to further realise NATO's criteria for entry. The next step would be the establishment of a Membership Action Plan for Kosovo, which ought to be designed according to the needs of NATO and Kosovo. The MAP would have a direct and profound impact in preparing Kosovo for membership talks. Pending successful and positive results while in the MAP programme, the final step would be the extension of an official invitation to start membership talks between NATO and Kosovo.

\section{Conclusion}

NATO remains the only organization of its kind in the world which continues to abide by its original purpose and mission of upholding the values of democracy, human rights, the market economy and peaceful solutions for international disagreements. In its more than 60 years of existence, NATO has managed to preserve the security and freedom of its members. It has only once occurred that a member state invoked Article 5 of the Treaty, which was related to the $9 / 11$ attacks. This shows that NATO's cohesion, capabilities and determination of its members to abide by their commitments has served as an effective deterrent force against any possible attacker. Today, NATO is a much larger and stronger alliance facing a multitude of challenges. NATO adopts its mission according to new security environments and challenges it faces, such as the expansion of the interpretation of Article 5 and its role beyond its geographical boundaries (Borawski and Young 2001). NATO's open door policy is still active and the case of Montenegro sends an 
important signal for the countries of the region about future accession in the organization.

Kosovo is still a state in transition, struggling to consolidate its democracy amidst the processes of normalization of relations with Serbia and full integration of Kosovan Serbs into state institutions and daily life. Kosovo struggles to overcome its transition period and become a fully functional democratic state. Facing these challenges, Kosovo still needs the help of international organizations and NATO. In particular, integration of Kosovan Serbs is directly dependent on the state of relations between Kosovo and Serbia. Until these issues are resolved, Kosovo remains a consumer of security.

There remain three issues that prima facie seem to prevent Kosovo in furthering its integration into NATO. The four non-recognizing NATO members continue to keep their oppositional stance towards the political status of Kosovo, thus blocking any formal steps towards a formal relationship. Furthermore, UNSC Resolution 1244 is a serious obstacle. It seems complicated for NATO to overcome this resolution to boost the integration process. NATO and the UN have enhanced their relations recently and NATO might be reluctant to take any action that would trigger negative reaction by any permanent member of the UNSC. In the end it is important for Kosovo to overcome its internal political instability and its relations with its neighbours, especially Serbia, enabling it to become a security generator and thus prove to be an added value to NATO. Having these challenges in mind, Kosovo might find it very difficult to move forward with an integration process we have so far seen applied to other states. Nevertheless, NATO might design a sui generis mechanism which would not jeopardize its internal unity and also its stance in global relations, in particular its relations with the UN. The EU example, by entering into a contractual relationship with Kosovo, might just be one example of how NATO can overcome its internal division and move forward to place Kosovo in its PfP programme. In the meantime, Kosovo should make use of its integration process with the EU to also meet standards which are compatible to NATO. This would help to speed up the process when the formal integration process starts. 
On a positive note, Kosovo has made formal guarantees to uphold the highest standards related to democracy, human and minority rights and the functioning of the market economy. The Constitution of Kosovo sets the stage for Kosovo to abide by the values embraced by NATO. It is of paramount importance for Kosovo to continue consolidation of its state, normalization of relations with Serbia and the development of good neighbourhood relations. The role of the KSF might be very crucial in consolidating the state, in particular due to its high standards which are a result of close monitoring of its development by KFOR. Transformation of the KSF into a Kosovan Army would play a significant role in the concept of generating security and helping to preserve the security of NATO as a future member. 


\section{B Bibliography}

Accordance with International Law of the Unilateral Declaration of Independence in Respect of Kosovo, 2010, Advisory Opinion, I.C.J. Reports 2010.

Augustine, Z. P., 2014. Cyber Neutrality: A Textual Analysis of Traditional Jus in Bello Neutrality Rules Through a Purpose-Based Lens. Air Force Law Review, 71 (69): 71-93.

Borawski, J. and Young. T., 2001. NATO after 2000: The Future of the EuroAtlantic Alliance. Westpoint: Praeger.

Botticelli, A. D., 2002. The Premier of the North Atlantic Treaty's Article V: Is Article $V$ still a Deterrent?. Suffolk Transnational Law Review, 26(51): 51-80.

Bytyci, F., 2017. NATO, U.S. slap Kosovo's move to create national army. Reuters, 8 March [online]. Available at: http://www.reuters.com/ article/Us-kosovo-army-idUSKBN16F1GE (Accessed 2 August 2017).

Clewlow, A., 2010. The Kosovo Protection Corps: A Critical Study of its De-activation as a Transition. Hambros: Norwegian Institute of International Affairs.

Dudziak, M. L., 2012. Law, Power, and "Rumors of War": Robert Jackson Confronts Law and Security after Nuremberg. 60 Buffalo Law Review 367.

European Commission, n.d.a. European Neighborhood Policy and Enlargement, Country Reports, Kosovo. Available at: http:// ec.europa.eu/enlargement/countries/package/index_en.htm (Accessed on 20 April 2017).

European Commission, n.d.b. Kosovo. [online]. Available at: http:// ec.europa.eu/enlargement/countries/detailed-countryinformation/kosovo/index_en.htm (Accessed 30 May 2017).

European Council, 2015. Stabilization and Association Agreement (SAA) between the European Union and Kosovo signed. 27 October 
[online]. Available at: http://www.consilium.europa.eu/en/press/ press-releases/2015/10/27-kosovo-eu-stabilisation-associationagreement/ (Accessed 30 May 2017).

Hopkins, J., 2017. Kosovo Leader's Military Maneuvers. Politico, 4 April [online]. Available at: http://www.politico.eu/article/hashim-thacikosovo-leaders-military-maneuvers/ (Accessed 2 August 2017).

Ministry of Foreign Affairs of Iceland. Iceland and NATO. [online]. Available at: https://www.mfa.is/foreign-policy/security/iceland-nato/ (Accessed 1 April 2017).

Kennan, G. F., 1947. The Sources of Soviet Conduct. Foreign Affairs, July [online]. Available at: https://www.foreignaffairs.com/articles/ russian-federation/1947-07-01/sources-soviet-conduct (Accessed 3 April 2017).

Kosovo Parliament, 2008. Kosovo Declaration of Independence. Prishtina. Kosovo Parliament, 2008. Constitution of the Republic of Kosovo. Prishtina: Official Gazette.

NATO, 1999. NATO's role in relation to the conflict in Kosovo. [online]. Available at: http://www.nato.int/kosovo/history.htm (Accessed 15 May 2017).

NATO, 2008. 1995 Study of NATO Enlargement. [online]. Available at: http:// www.nato.int/cps/en/natohq/official_texts_24733.htm (Accessed 20 May 2017).

NATO, 2013. NATO Declares Kosovo Security Force Fully Operational. [online]. Available at: http://shape.nato.int/-nato-declares-kosovosecurity-force-fully-operational (Accessed 22 April 2017).

NATO, 2014a. Euro-Atlantic Partnership Council. [online]. Available at: http://www.nato.int/cps/en/natolive/topics_49276.htm (Accessed 3 April 2017).

NATO, 2014b. NATO's relations with the United Nations. [online]. Available at: http://www.nato.int/cps/en/natohq/topics_50321.htm (Accessed 20 May 2017).

NATO, 2015a. Collective Defence-Article 5. [online]. Available at: http:// 
www.nato.int/cps/is/natohq/topics_1 10496.htm (Accessed 3 June 2017).

NATO, 2015b. Membership Action Plan (MAP). [online]. Available at: http://www.nato.int/cps/en/natolive/topics_37356.htm (Accessed 10 May 2017).

NATO, 2015c. The North Atlantic Council. [online] Available at: http:// www.nato.int/cps/en/natolive/topics_49763.htm (Accessed 20 May 2017).

NATO, 2016. NATO Strategic Concept. [pdf]. Available at: http://www. nato.int/lisbon2010/strategic-concept-2010-eng.pdf (Accessed 15 May 2017).

NATO, 2017. Montenegro Joins NATO as 29th Ally. [online]. Available at: http://www.nato.int/cps/en/natohq/news_144647. htm?utm_source=facebook\&utm_medium=smc\&utm_ campaign=170605+montenegro (Accessed 6 June 2017).

NATO, n.d.a. NATO's Role in Kosovo. [online]. Available at: http://www. nato.int/summit2009/topics_en/04-kosovo.html (Accessed 22 May 2017).

NATO, n.d.b. KFOR Objectives. [online]. Available at: http://jfcnaples. nato.int/kfor/about-us/history/kfor-objectives (Accessed 25 May 2017).

NATO, n.d.c. NATO Mission. [online]. Available at: http://www.shape.nato. int/kfor/about-us/mission (Accessed 20 April 2017).

NATO Public Diplomacy Division, 2006. NATO Handbook. Brussels.

Office of the Prime Minister of Kosovo, 2012. Agreed Conclusions on Regional Representation and Cooperation of 24 February 2012. [pdf]. Available at: http://www.kryeministri-ks.net/repository/docs/ Konkluzionet_0210_arranzhime.pdf (Accessed 30 May 2017).

Office of the Prime Minister of Kosovo. The Agreements of the Technical Dialogue and the Agreement of Dialogue of Normalization. [online] Available at: http://www.kryeministri-ks.net/?page=2,5 (Accessed 30 May 2017). 
Sputnik, 2013. Kosovo's 'Irresponsible' Intention to Create Army Imperils Europe-Moscow. Sputniknews, 16 March [online]. Available at: https://sputniknews.com/politics/201703161051653326-kosovoarmy-balkans-europe-russia/ (Accessed 1 August 2017).

Stavridis, J., 2016. NATO's Turn to Attack. Foreign Policy, 14 November [online]. Available at: http://foreignpolicy.com/2015/11/14/natosturn-to-attack-paris-terrorist-isis/ (Accessed 15 May 2017).

Teson, F. R., 2009. Kosovo: A powerful precedent for the Doctrine of Humanitarian Intervention. Amsterdam Law Forum, 1 (2): 42-48.

The Former Yugoslav Republic of Macedonia v. Greece (2011), ICJ, General List no. 142.

The North Atlantic Treaty, 34 UNTS 243, 4 April 1949.

Todd, G. H., 2009. Armed Attack in Cyberspace: Deterring Asymmetric Warfare with an Asymmetric Definition. Air Force Law Review, 64(65): 66-101.

UN Charter, 1 UNTS XVI, 24 October 1945.

UNSC Resolution 1244 S/RES/1244, 10 June 1999.

Walker, E. W., 2015. Between East \& West: NATO Enlargement \& the Geopolitics of the Ukraine Crisis. E-International Relations, 13 April [online]. Available at: http://www.e-ir.info/2015/04/13/betweeneast-west-nato-enlargement-the-geopolitics-of-the-ukraine-crisis/ (Accessed 15 March 2017).

Wiseman, J. W., 2001. Transformation of the Kosovo Liberation Army: A Way to an End. Carlisle Barracks, PA: Army War College.

Besfort T. Rrecaj (besfort.rrecaj@uni-pr.edu) is Professor of International Law and Relations at the University of Prishtina "Hasan Prishtina" and President of the Euro-Atlantic Association of Kosovo. Professor Rrecaj was visiting Professor for several years at the Inter-University Center Dubrovnik. Currently, Professor Rrecaj holds the position of Vice Dean for Education 
a and Academic Affairs with the Faculty of Law at the University of Prishtina "Hasan Prishtina". Professor Rrecaj received his education from different European and US Universities: State University of New York at the Buffalo Law School, the Vienna Diplomatic Academy, and the University of Prishtina. Professor Rrecaj focuses his research on issues related to regional and international security, human rights, principles of public international law and international organizations. He has published his articles with renowned European and US journals and publishers. Throughout his career Professor Rrecaj has held different high level positions with the Government and Judiciary of Kosovo such as: Senior Legal Adviser with the Constitutional Court, Senior Political Adviser, Chief Executive Officer with the Ministry of Foreign Affairs and the Ministry for European Integration. For more see: http://juridiku.uni-pr.edu/ Dekanati/Prodekan-per-qeshtje-mesimore.aspx. 